\title{
A predatory Rusophycus burrow from the Cambrian of southern New Brunswick, eastern Canada
}

\author{
Ron K. Pickerill and Donovan Blissett \\ Department of Geology, University of New Brunswick, P.O. Box 4400, Fredericton, New \\ Brunswick E3B 5A3, Canada
}

Date Received: November 13, 1999

Date Accepted: April 28, 2000

\begin{abstract}
A specimen of the trilobite-produced trace fossil Rusophycus is intimately associated with the annelid-produced meandering burrow Helminthopsis hieroglyphica on the upper surface of an amalgamated quartz arenite of the King Square Formation (late Middle - early Late Cambrian), Saint John Group, southern New Brunswick. Observations suggest that the rusophycid reflects, and is a rather unusual example of, predatory behaviour. Similar, but rare, examples have only occasionally been reported in the geologic record. The occurrence documented herein is the first from strata of this age and also the first from Canada.
\end{abstract}

Un spécimen d'une trace fossilisée de trilobite de l'espèce Rusophycus est directement reliée au tube méandrique produit par des annelidés Helminthopsis hieroglyphica sur la surface supérieure de l'assemblage de quartz arenite de la formation de King Square (fin du Cambrien intermédiaire au début du Cambrien supérieur), groupe de Saint-Jean, dans le sud du Nouveau-Brunswick. Les observations portent à croire que l'activité rusophycide reflète et traduit même un exemple assez inusité de prédation. D'autres exemples semblables, mais rares, ont à l'occasion été observés dans l'histoire géologique. L'exemple cité ici est le premier obtenu dans un étage de cet âge et également le premier du genre au Canada.

Traduit par la rédaction

\section{INTRODUCTION}

Trace fossils in the Cambrian-Lower Ordovician Saint John Group of southern New Brunswick were first recorded by Matthew (1888 a, b, c, 1890). Yet it is only recently that additional discoveries have been documented in some detail (Tanoli 1987; Hofmann and Patel 1989), the latter authors describing ichnotaxa from the basal Ratcliffe Brook Formation (equivalent to the Ratcliffe Brook Group of Landing (1996)) and Tanoli those from the remainder of the sequence. Of additional note is the work of Fillion and Pickerill (1990), who reassessed taxonomically some of Matthew's material and demonstrated that several of his so-called ichnotaxa were in all probability inorganic in origin. Further work by us on the sequence has essentially confirmed the observations made by Tanoli (1987) but also has resulted in the discovery of a unique specimen that we describe and discuss herein.

\section{LOCATION AND GENERAL GEOLOGY}

The material documented herein occurs on the upper surface of an amalgamated $50 \mathrm{~cm}$ thick, steeply dipping, parallel-laminated quartz arenite layer exposed on the northwestern side of the McKay Highway, immediately below Wright Street which runs parallel to the highway, east Saint John, southern New Brunswick (Fig. 1). The location is the same as that documented by Pickerill (1982), who described the occurrence of cnidarian medusoids from a similar sandstone layer from approximately $5 \mathrm{~m}$ lower in the sequence. Exposure at the McKay Highway comprises interbedded, fine- to medium-grained micaceous quartz arenites $(20-70 \mathrm{~cm}$ thick) and silty shales $(1-5 \mathrm{~cm}$ thick) and constitutes part of the ca. $380 \mathrm{~m}$ thick King Square Formation (Tanoli and Pickerill 1988) of the CambroOrdovician Saint John Group. More recently, Landing (1996) proposed abandonment of the King Square Formation (equivalent to the previously defined Hastings Cove, Agnostus Cove and Black Shale Brook formations of Hayes and Howell (1937)) and suggested a more regionally applicable descriptor McLean Brook Formation as a replacement. Notwithstanding, the sequence includes late Middle - early Late Cambrian strata that were deposited on a storm-dominated shelf, the sandstones representing turbidites and/or tempestites and the silty shales fair-weather deposits (see Tanoli and Pickerill (1989) for details).

\section{SPECIMEN DESCRIPTION}

Fig. 2

As noted, the specimen, uncollectible, occurs on the upper surface of an amalgamated $50 \mathrm{~cm}$ thick, micaceous quartz arenite layer. It comprises a composite ichnotaxon (sensu Pickerill 1994) consisting of the arthropod-produced (trilobite) impression Rusophycus isp. superimposed on the annelidproduced (see Han and Pickerill 1995; Wetzel and Bromley 1996) simple horizontal burrow Helminthopsis hieroglyphica. The latter is a freely meandering burrow that possesses 


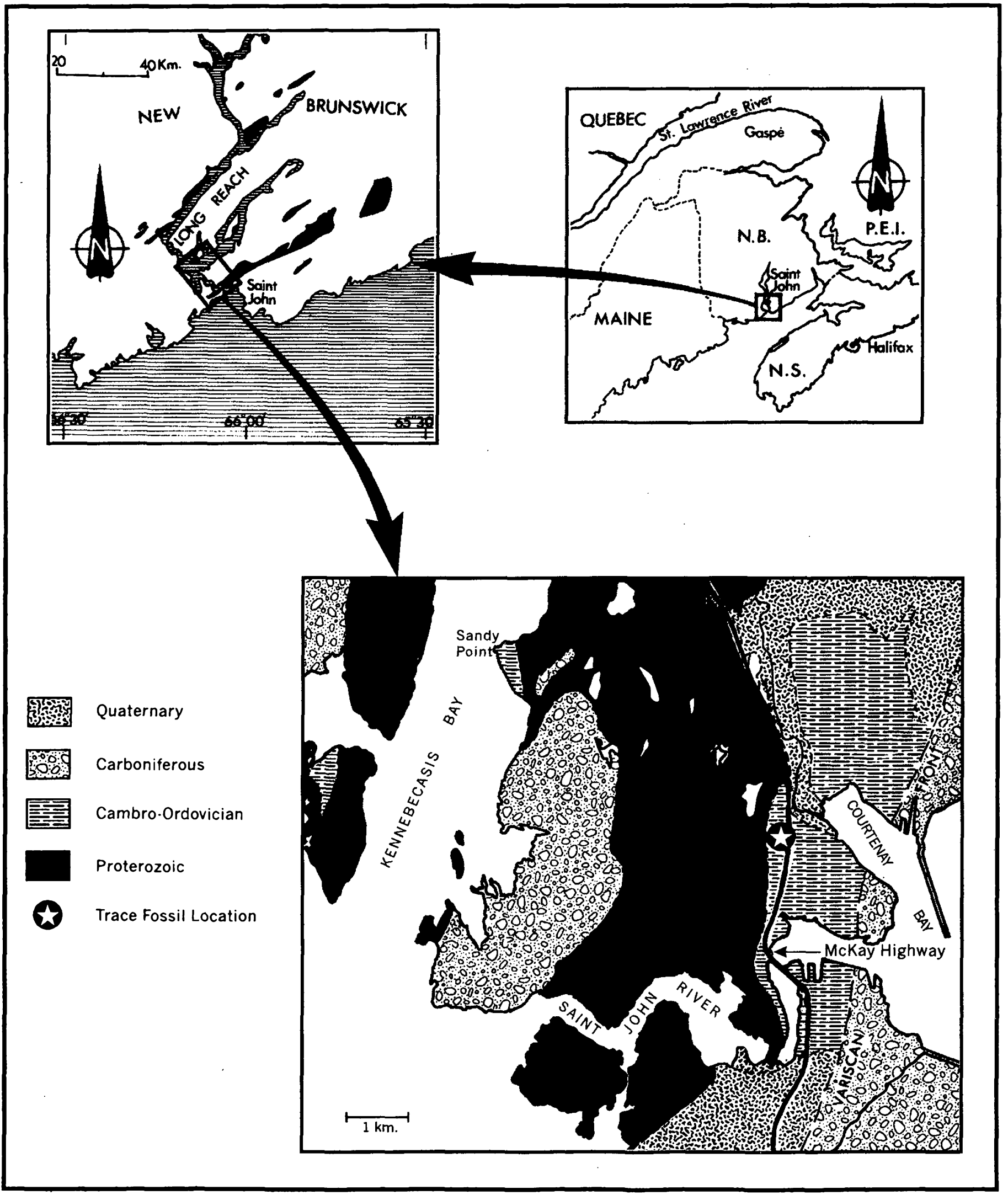

Fig. 1. Location and generalized geological map of the Saint John area of southern New Brunswick (after Pickerill 1982). The star in the lower figure indicates the location of the material described herein (see text for details). 

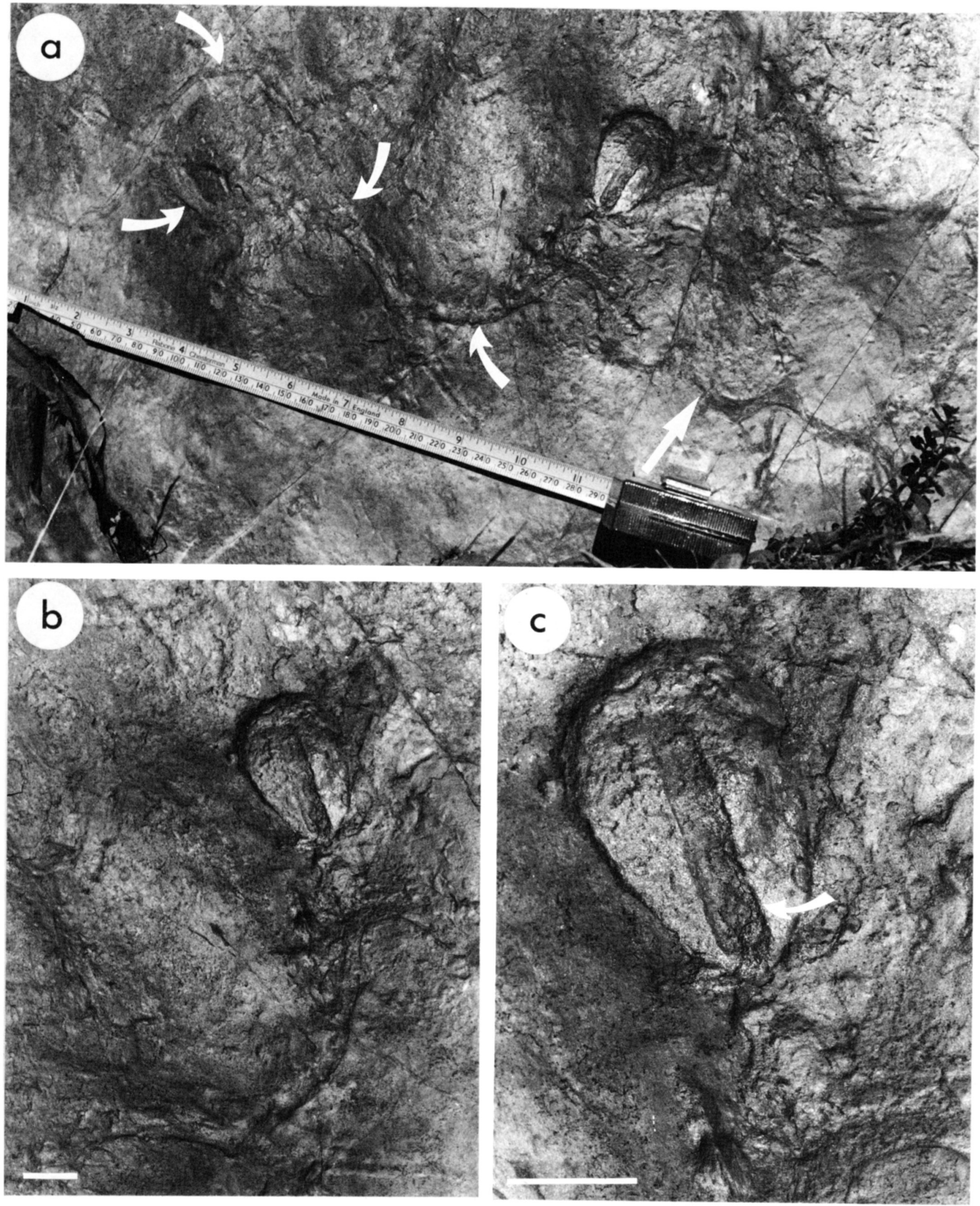

Fig. 2. Photographs of the material documented herein; upper surface of an amalgamated quartz arenite layer, McKay Highway, Saint John, New Brunswick. Recurved arrows in a, illustrate the course of Helminthopsis hieroglyphica that is cut secondarily by an example of Cochlichnus (straight arrow); scale in inches and centimetres. b, and, particularly, c, are enlargements of Rusophycus illustrating its expanded anterior and anterolateral margins and the axial association of $H$. hieroglyphica (arrowed in c) that terminates towards its anterior end; bar scales are $1 \mathrm{~cm}$. 
straight segments, is $8-12 \mathrm{~mm}$ wide and extends $15 \mathrm{~mm}$ from the anterior and axial end of the rusophycid for a total distance of approximately $150 \mathrm{~mm}$. It is preserved essentially in positive relief though small segments are preserved in negative epirelief. The $33 \mathrm{~mm}$ long extension associated with Rusophycus is, however, distinctly flattened and is slightly wider than the remainder of the trace.

The Rusophycus tapers posteriorly, is relatively small, $\mathbf{4 4}$ $\mathrm{mm}$ long and a maximum width of $30 \mathrm{~mm}$ toward its anterior end, and is shallowly impressed to a depth of only several millimetres. Nevertheless, it is clearly bilobate; individual lobes are smooth and merge posteriorly. The anterior and anterolateral margins exhibit slightly extended impressions that may possibly represent cephalic and genal spine markings of the producing arthropod. The smooth character of the lobes, presumably a reflection of impression into a coarse-grained substrate, precludes ichnospecific assignment of the rusophycid that elsewhere is based to a large degree on the nature and disposition of associated scratch markings (see Fillion and Pickerill 1990).

\section{Discussion AND CONCLUSIONS}

Most workers (e.g., Seilacher 1985; Goldring 1985) are of the consensus that Rusophycus was produced intrastratally, and in marine environments by burrowing arthropods, more specifically trilobites. As discussed by Pickerill (1995), however, a surficial origin can in certain examples be equally plausible, particularly those demonstrating rheotactic orientation. With the particular example of Rusophycus documented herein, however, an intrastrated origin appears unequivocal as the specimen is intimately associated with and clearly intersects and post-dates the infaunally produced burrow of Helminthopsis hieroglyphica, the latter a product of a worm-like organism, most likely a polychaete annelid (see Han and Pickerill 1995; Wetzel and Bromley 1996). $H$. hieroglyphica was clearly produced infaunally as it is now preserved essentially in positive epirelief, a preservational style inconsistent with a surficial origin. It appears likely, therefore, that at the time of its production the annelid was deposit feeding along a mud-sand interface, now represented by only the upper surface of the amalgamated quartz arenite.

Traditionally Rusophycus has been interpreted as an arthropod cubichnion produced as a product of stationary digging for the purposes of resting or sheltering (Seilacher 1955; Osgood 1970). However, other authors (Bergstrom 1973; Jensen 1990; Brandt et al. 1995) have presented strong evidence that at least some examples of Rusophycus can best be interpreted as predatory hunting burrows. Bergstrom (1973), and more particularly Jensen (1990), described Rusophycus dispar intimately associated with teichichniantype burrows from the Lower Cambrian of Sweden, and Brandt et al. (1995) $R$. carleyi mutually associated with Palaeophycus from the Ordovician of Ohio. Other possible examples, though not fully described or discussed in detail by their respective authors, include those of Martinsson (1965) from the Middle Cambrian of Sweden and Osgood and Drennen (1975) from the Silurian of New York. In all these examples the common factors attributed to predator-prey interaction were suggested to be (i) the more or less central superimposition and parallel alignment of the trilobite traces at a distance of at least two thirds or more from their anterior ends, and (ii) that the trilobite traces clearly post-dated the annelid-produced burrows (discussed in more detail in Jensen (1990) and Brandt et al. (1995)). As noted by Brandt et al. (1995) such evidence for predation, while compelling, may not necessarily be totally conclusive. However, alternative explanations are also not entirely satisfactory. The observable portion of the steeply dipping bedding plane surface of the King Square Formation preserves many other examples of the annelid-produced ichnotaxa Helminthopsis, Planolites and, less commonly, Cochlichnus. Yet none of these are intersected by additional examples of Rusophycus. Indeed, the rusophycid documented here is the only example present on this particular surface. We therefore believe that it would have been highly fortuitous for the producing trilobite to have randomly intersected $H$. hieroglyphica other than for predatory purposes, particularly as our observations are in total accord with those previously suggested criteria for the recognition of predatorprey interaction. If our interpretation is correct, the slightly expanded and flattened portion of $H$. hieroglyphica, that occurs only when in association with the rusophycid, may well reflect compaction of the burrow by the trilobite while actively devouring its prey.

In addition to its rather unique preservation in negative relief (all other reported specimens are preserved as positive hyporeliefs) the recording of this predatory rusophycid burrow is the first from strata of late Middle Cambrian - early Late Cambrian age. Furthermore it is the first example to be reported from any Paleozoic sequence in Canada and, as such, represents a unique and fortuitous occurrence that we regard as important to have documented.

\section{ACKNOWLEDGEMENTS}

We thank Bob McCulloch for photographic work and Elaine Pickerill for typing the manuscript. Encouraging reviews were provided by Robert Metz and Guy Narbonne. This work was undertaken during the tenure of an NSERC Operating Grant to the senior author, which is gratefully acknowledged.

\section{REFERENCES}

BERGSTROM, J. 1973. Organization. life and systematics of trilobites. Fossils and Strata, 2, 69p.

BRANDT, D.S., MEYER, D.L., \& LASK, P.B. 1995. Istotelus (Trilobita) "Hunting burrow" from Upper Ordovician strata, Ohio. Journal of Paleontology, 69, pp. 1079-1083.

FILLION, D., \& PICKERILL, R.K. 1990. Ichnology of the Upper Cambrian? to Lower Ordovician Bell Island and Wabana groups of eastern Newfoundland, Canada. Palaeontographica Canadiana, 7, 119p.

GOLDRING, R. 1985. The formation of the trace fossil Cruziana. Geological Magazine, 122, pp. 65-72.

HAN, Y., \& PICKERILL, R.K. 1995. Taxonomic review of the ichnogenus Helminthopsis Heer 1877 with a statistical analysis of selected ichnospecies, Ichnos, 4, pp. 83-118.

Hayes, A.O., \& Howell, B.F. 1937. Geology of Saint John. Geological Society of America, Special Paper, 5, 146p.

Hofmann, H.J., \& PATEL, I.M. 1989. Trace fossils from the type "Etchiminian Series" (Lower Cambrian Ratcliffe Brook 
Formation), Saint John area New Brunswick, Canada. Geological Magazine, 126, pp. 139-157.

JENSEN, S. 1990. Predation by early Cambrian trilobites on infaunal worms - evidence from the Swedish Mickwitzia Sandstone. Lethaia, 23, pp. 29-42.

LANDING, E. 1996. Avalon: Insular continent by the latest Precambrian. In Avalonian and Related Peri-Gondwana Terranes of the Circum North Atlantic. Edited by R.D. Nance and M.D. Thompson. Geological Society of America, Special Paper 304, pp. $29-63$.

MARTinsson, A. 1965. Aspects of a middle Cambrian thanatope on Öland. Geologiska Föreningens i Stokholm Förhandlingar, 87, 181-230.

MatThEW, G.F. 1888a. On Psammichnites and the early trilobites of the Cambrian rocks in eastern Canada. American Geologist, 2, pp. 1-9.

MATthew, G.F. $1888 \mathrm{~b}$. On a basal series of Cambrian rocks of Acadia. Canadian Record of Science, 3, pp. 21-29.

MATTHEW, G.F. 1888c. On the classification of Cambrian rocks in Acadia. Canadian Record of Science, 3, pp. 71-81.

MATTHEW, G.F. 1890. On Cambrian organisms in Acadia. Transactions of the Royal Society of Canada, Section 4, 7, pp. 135-162.

OsGoOD, R.G. 1970. Trace fossils of the Cincinnati area Paleontographica Americana, 6 (41), pp. 281-444.

OSGOOD, R.G., AND DRENNEN, W.T. 1975. Trilobite trace fossils from the Clinton Group (Silurian) of east-central New York State. Bulletin of American Paleontology, 67 (287), pp. 300 348.

PICKERILL, R.K. 1982. Cambrian medusoids from the St. John Group, southern New Brunswick. In Current Research, Part B, Geological Survey of Canada, Paper 82-1B, pp. 71-76.
PICKERILL, R.K. 1994. Nomenclature and taxonomy of invertebrate trace fossils. In The Palaeobiology of Trace Fossils. Edited by $\mathrm{S}$. K. Donovan, Wiley, Chichester, pp. 3-42.

PICKERILL, R.K. 1995. Deep-water marine Rusophycus and Cruziana from the Ordovician Lotbinière Formation of Quebec. Atlantic Geology, 31, pp. 103-108.

SEILACHER, A. 1955. Spuren und Lebensweise der Trilobiten. In Beitrăge zur Kenntniss des Kambriums in der Salt Range (Pakistan). Edited by O. H. Schindewolf and A. Seilacher. Akademie der Wissenschaften und der Litteratur. Abhandlungen der Mathematisch - Naturwissenschaftlichen Klasse 1955, pp. 86-116.

SEILACHER, A. 1985. Trilobite palaeobiology and substrate. Transactions of the Royal Society of Edinburgh. Earth Sciences, 76, pp. 231-237.

TANOLI, S.K. 1987. Stratigraphy, sedimentology and ichnology of the Cambrian - Ordovician Saint John Group, southern New Brunswick, Canada. Unpublished Ph.D. thesis, University of New Brunswick, 436p.

TANOLI, S.K., \& PICKERILL, R.K. 1988. Lithostratigraphy of the Cambrian - Early Ordovician Saint John Group, southem New Brunswick. Canadian Journal of Earth Sciences, 25, pp. 669 690.

TANOILI, S.K., \& PiCKerILL, R.K. 1989. Cambrian shelf deposits of the King Square Formation, Saint John Group, southern New Brunswick. Atlantic Geology, 25, pp. 129-141.

Wetzel, A., \& BRomley, R.G. 1996. Re-evaluation of the ichnogenus Helminthopsis - a new look at the type material. Palaeontology, 39, pp. 1-19.

Editorial responsibility: Graham L. Williams 


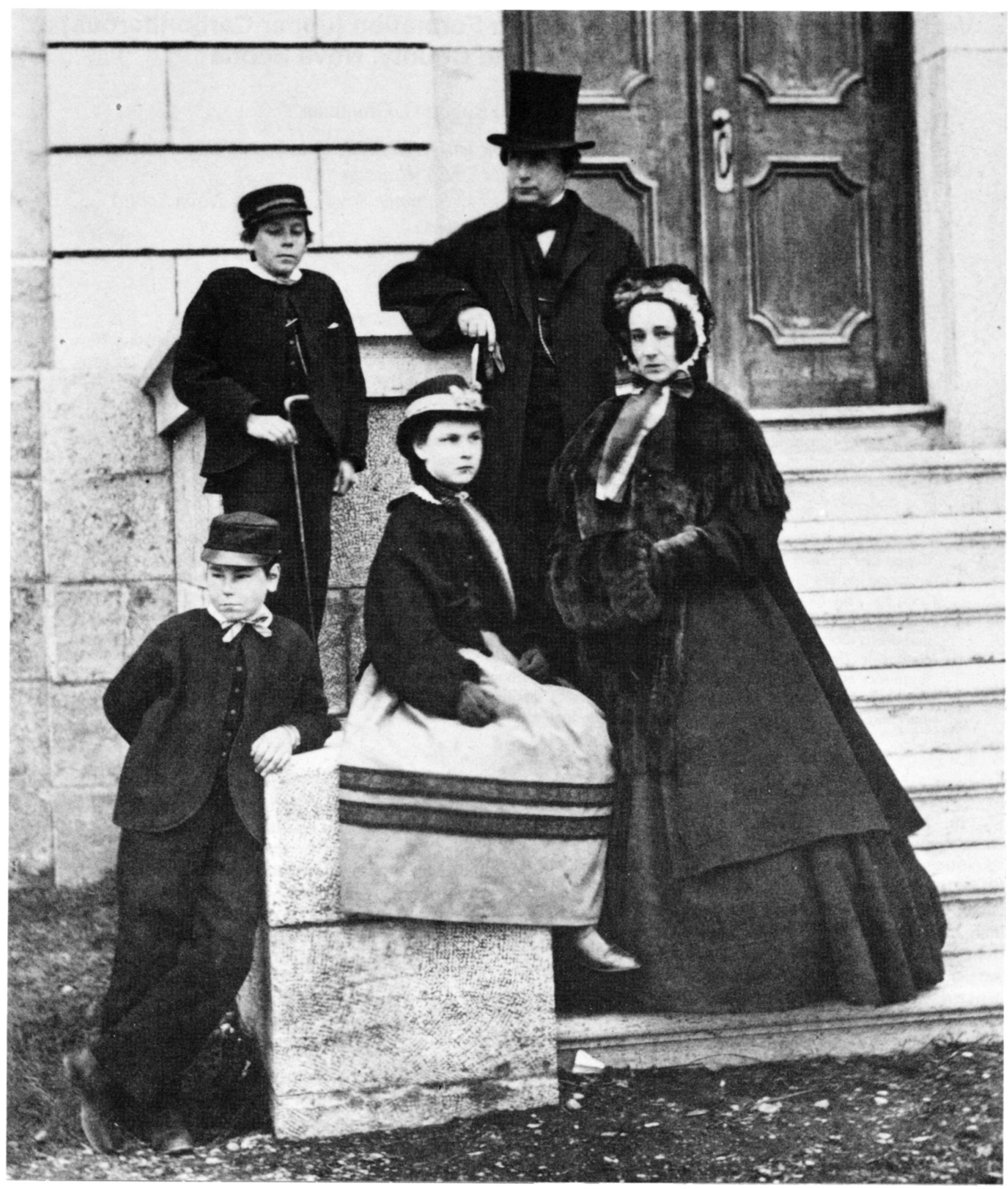

Frontispiece. Photograph taken on the steps of the Arts Building at McGill College, Montreal, ca. 1865, showing Sir John William Dawson, his wife Margaret Ann Young (Mercer), sons George Mercer (holding cane) and William Bell, and daughter Anna Lois. The Dawsons also had a (younger) daughter Eva and two other sons, James Cosmo, who died in infancy, and Rankine. Photograph courtesy of the Notman Photographic Archives, McCord Museum of Canadian History, Montreal. 